\title{
Heavy Metals Content of Two Red Soils in Samar, Philippines
}

\author{
Ian A. Navarrete ${ }^{1,2}$ and Victor B. Asio ${ }^{2}$ \\ ${ }^{1}$ Laboratory of Environmental Soil Science, Obihiro University of Agriculture and \\ Veterinary Medicine, Inada-cho 080-8555, Japan; ${ }^{2}$ Department of Agronomy and Soil \\ Science, Visayas State University, Baybay City, Leyte 6521-A Philippines
}

\begin{abstract}
The study evaluated the total and available heavy metal $(\mathrm{Cd}, \mathrm{Cu}, \mathrm{Cr}, \mathrm{Pb}, \mathrm{Ni}$, and $\mathrm{Zn}$ ) contents of two red soils in Samar, Philippines, one developed from slate near a mining site (Bagacay soil) and the other from serpentinite (Salcedo soil), a well-known source of heavy metals. Soil samples were collected from every horizon in each profile and samples were digested using aqua regia and $\mathrm{NH}_{4} \mathrm{NO}_{3}$ to determine total and available heavy metals content, respectively. Results revealed that Salcedo soil had high contents of total $\mathrm{Cr}$ (average: $1353 \mathrm{mg} \mathrm{kg}^{-1}$ ), total $\mathrm{Ni}$ (average: $610 \mathrm{mg}$ $\mathrm{kg}^{-1}$ ), and available $\mathrm{Cr}$ (average: $0.19 \mathrm{mg} \mathrm{kg}^{-1}$ ) that exceeded the maximum allowable contents in agricultural soils but it had low amounts of the available form of the heavy metals. Bagacay soil showed very low contents of both total and available heavy metals due to their low amounts in the parent rock. The red Bagacay soil showed no effect of the nearby mining activity.
\end{abstract}

Keywords: heavy metals, soil pollution, red soils, Samar island, mining, serpentinite

Correspondence: VBAsio Address: Department of Agronomy and Soil Science, Visayas State University, Baybay City, Leyte, 6521-A Philippines. Tel: 053-335-2627 Email: vbasio_ph@ yahoo.com

DOI: $10.32945 /$ atr3329.2011 


\section{INTRODUCTION}

Heavy metals generally occur in rocks in small amounts but concentrations in soils are frequently elevated as a result of humancaused contamination. The most important heavy metals with regard to potential hazards and occurrence in contaminated soils are: arsenic (As), cadmium $(\mathrm{Cd})$, chromium $(\mathrm{Cr})$, mercury $(\mathrm{Hg})$, lead $(\mathrm{Pb})$ and zinc $(\mathrm{Zn})$. The sources of heavy metal pollutants are metal mining, metal smelting, metallurgical industries, and other metal-using industries, waste disposal, corrosions of metals in use, agriculture and forestry, fossil fuel combustion, and sports and leisure activities (Alloway, 1995 $\&$ 1997).

Heavy metal pollution of soils is a global environmental problem. The growing scientific and public awareness on this problem arises because heavy metal pollutants pose health risk for humans through food chain transfer from soils to crops (Alloway 1995; Oliver 1997; Chen and Lee, 1995; Chen et al., 2000) especially in hot spots located close to industrial sites, around large cities, and in the vicinity of mining and smelting plants (Puschenreiter et al., 2005).

Heavy metal pollution of soils can also be due to the high contents of heavy metals of the parent material particularly the ultramafic and serpentinite rocks (Huang, 1962; Reeves, 2003). The danger posed by such naturally polluted soils is that people living in the area may not be aware about the soil pollution. Thus, any soil studies and land evaluation activities in or close to ultramafic and serpentinite areas and mining sites should include an assessment of heavy metal contamination.

The present study evaluated the levels of total and available heavy metals of two major red soils in Samar island one of which developed from slate close to a mining site, and the other from serpentinite. We hypothesized that the two soils contain high levels of heavy metals coming from their parent material and possibly from the nearby mining activity. 
MATERIALS AND METHODS

Study Site

The study was conducted in Samar, the $4^{\text {th }}$ largest island member of the Philippine archipelago (Fig. 1). Two study sites were selected,

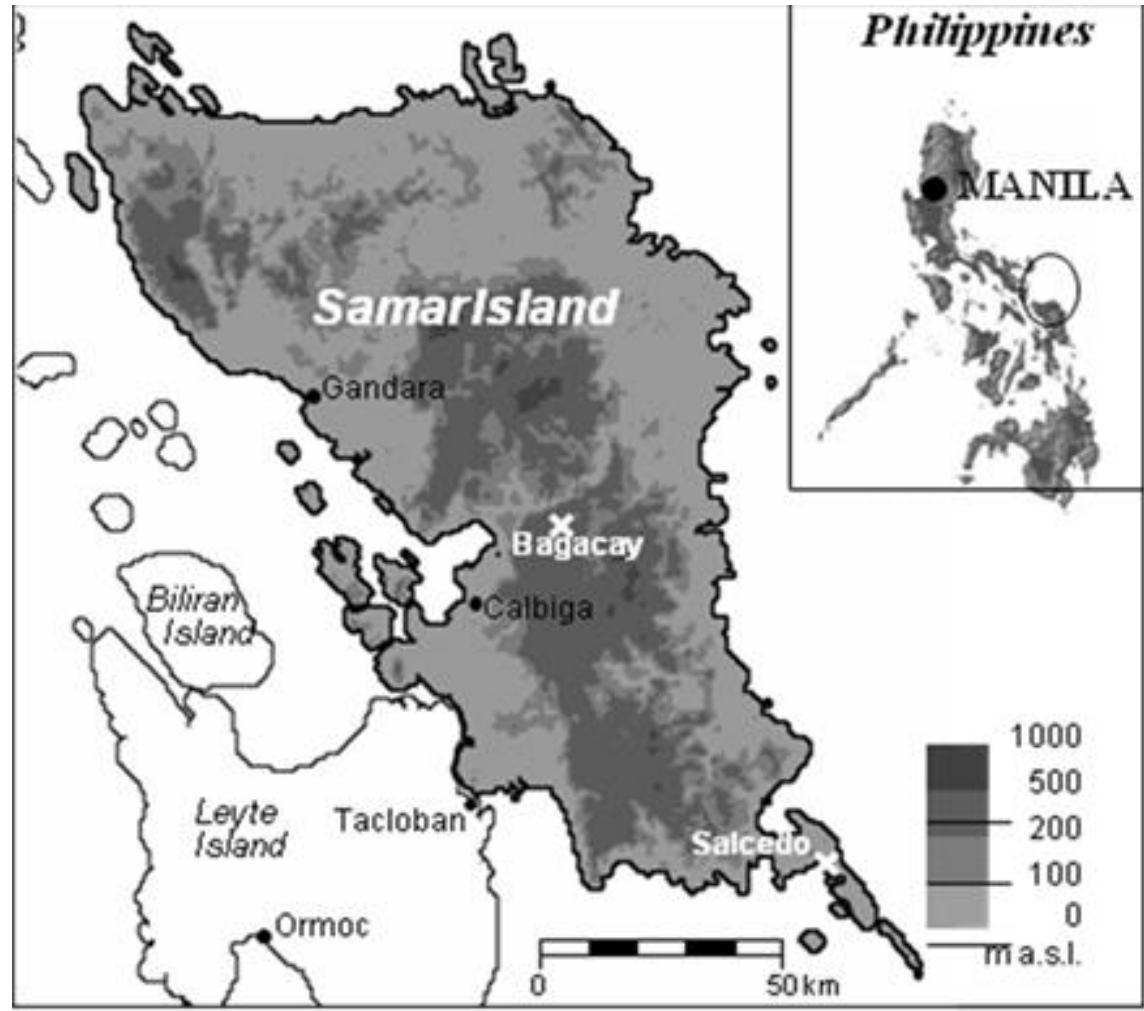

Figure 1. Map of Samar, Philippines and the location of the research sites marked X.

the first located at an altitude of 600-650 $\mathrm{m}$ ASL on a dissected plateau in the central portion of the island in a place called Bagacay, which is widely known for its copper and pyrite mines (stopped some years ago). The site is underlain by slate of Lower Miocene age, which developed into the red soil classified as Haplic Acrisol (World Reference Base), or Typic Paleudult (Soil Taxonomy) (Navarrete et al., 2007). The area is a residual forest dominated by dipterocarp tree species. The second 
site is located in the southeastern portion of the island in the coastal town of Salcedo. The area is hilly with an altitude of $50 \mathrm{~m} \mathrm{ASL}$ and is covered with patches of dipterocarp trees and grasses. A major plant common to both sites is the fern Pteridium aquilinum. The red soil in the area which is classified as Haplic Ferralsol (World Reference Base) or Rhodic Hapludox (Soil Taxonomy) developed from serpentinite of Upper Cretaceous origin. Both red soils are highly weathered and contain considerable amounts of hematite, which explains their deep red color (Navarrete et al., 2007; Asio and Jahn, 2007). The climate of the two sites falls within the Köppen's Am type (tropical rain forest climate, monsoon type) having an annual rainfall of $2700 \mathrm{~mm}$ and average temperature of $28^{\circ} \mathrm{C}$. Selected physicochemical properties and clay mineralogy of the two soils are presented in Table 1 and Figure 2, respectively.

Table 1. Selected characteristics of the two red soils in Samar, Philippines

\begin{tabular}{|c|c|c|c|c|c|c|c|c|c|}
\hline \multirow[b]{2}{*}{ Horizon } & Depth & $\mathrm{pH}$ & Clay & $\mathrm{OM}$ & $\mathrm{CECpH}_{7}$ & Fed & Ald & Feo & Alo \\
\hline & $\mathrm{cm}$ & $\mathrm{H}_{2} \mathrm{O}$ & & & $\begin{array}{c}\mathrm{cmol} \\
\mathrm{kg}^{-1}\end{array}$ & \multicolumn{4}{|c|}{$\mathrm{g} \mathrm{kg}^{-1}$} \\
\hline \multicolumn{10}{|c|}{ Bagacay soil } \\
\hline $\mathrm{Ah}$ & $0-5$ & 5.8 & 27.1 & 4.42 & 29 & 64 & 8.3 & 5.2 & 2 \\
\hline BA & $5-20$ & 5.8 & 32.7 & 5.07 & 30.1 & 62 & 8.0 & 5.4 & 2 \\
\hline Bt1 & $20-60$ & 5.3 & 33.3 & 1.70 & 21.8 & 73 & 9.8 & 5.4 & 2.3 \\
\hline $\mathrm{Bt} 2$ & $60-100$ & 5.2 & 36.9 & 0.97 & 16.1 & 79 & 10.6 & 1.6 & 2.5 \\
\hline $\mathrm{Bt} 3$ & $100-165$ & 5.1 & 36.4 & 0.52 & 18 & 84 & 10.0 & 1.4 & 2.6 \\
\hline $\mathrm{Bt} 4$ & $165-225$ & 5.1 & 47.6 & 0.22 & 16.1 & 83 & 8.7 & 1.3 & 2.7 \\
\hline $\mathrm{Bt} 5$ & $225-275$ & 5.2 & 59.1 & 0.13 & 14.6 & 71 & 7.3 & 1.2 & 2.3 \\
\hline Bt6 & $275-350$ & 5.1 & 55.0 & 0.08 & 25.8 & 80 & 8.4 & 1.6 & 3.7 \\
\hline $\mathrm{Bt} 7$ & $350-500$ & 5.1 & 60.2 & 0.10 & 22.8 & 84 & 8.5 & 1.7 & 3.5 \\
\hline Bt8 & $500-550$ & 5.3 & n.d. & 0.07 & 19.8 & 71 & 7.1 & 2 & 2.2 \\
\hline \multicolumn{10}{|c|}{ Salcedo soil } \\
\hline $\mathrm{Ah}$ & $0-21$ & 5.8 & 59.8 & 1.38 & 9.7 & 164 & 21.6 & 1.4 & 1.4 \\
\hline Bo1 & $21-54$ & 5.7 & 63.6 & 0.43 & 9.7 & 191 & 24.0 & 1.4 & 1.7 \\
\hline Bo2 & $54-92$ & 5.5 & 69.0 & 0.33 & 10.9 & 194 & 23.2 & 1.4 & 1.8 \\
\hline Bo3 & $92-130$ & 5.6 & 75.8 & 0.28 & 11.1 & 180 & 20.0 & 1.3 & 1.7 \\
\hline Bo4 & $130-191$ & 5.6 & 83.8 & 0.23 & 10.9 & 170 & 16.4 & 1.4 & 1.8 \\
\hline Bo5 & $191-291$ & 5.5 & 85.3 & 0.16 & 20.7 & 154 & 13.6 & 1.1 & 2 \\
\hline Bo6 & 291-391 & 5.3 & 86.6 & 0.11 & 16.4 & 151 & 13.3 & 1.3 & 2.1 \\
\hline Bo7 & $391-500$ & 5.3 & 88.2 & 0.10 & 22.3 & 144 & 12.3 & 1.3 & 2.1 \\
\hline
\end{tabular}

*Selected data from Navarrete et al. (2007). 


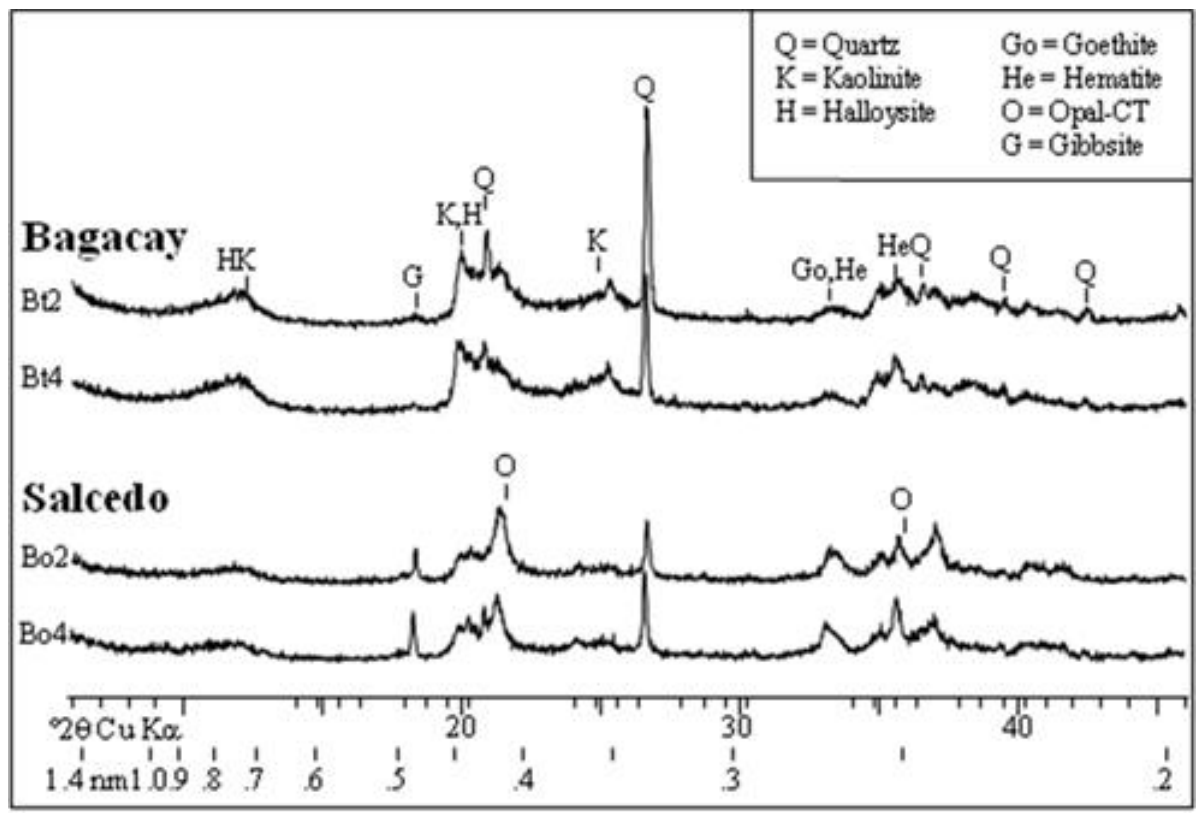

Figure 2. X-ray patterns of selected powdered soil samples.

\section{Soil Sampling and Analysis}

The two red soils were examined and sampled from recent road cuts after removing at least $30 \mathrm{~cm}$ thickness of surface to expose the fresh soil (Fig 3). Samples were collected from every horizon in each profile, freed of large plant residue, air-dried, and passed through a 2 mm sieve.

The total $\mathrm{Cd}, \mathrm{Cu}, \mathrm{Cr}, \mathrm{Pb}, \mathrm{Ni}$, and $\mathrm{Zn}$ were determined by aqua regia digestion method (USEPA 1986), which uses a mixture of concentrated $\mathrm{HNO}_{3}$ and $\mathrm{HCl}$ (1:3 proportion). This method is briefly described as follows: A $3 \mathrm{~g}$ soil is transferred into a digestion tube and $7 \mathrm{~mL}$ of concentrated $\mathrm{HNO}_{3}$ and $20 \mathrm{~mL}$ of concentrated $\mathrm{HCl}$ were added and allowed to stand overnight. Samples were digested with intermittent heat treatments at $50^{\circ} \mathrm{C}(5 \mathrm{~min}), 100^{\circ} \mathrm{C}(30 \mathrm{~min})$, and $120^{\circ} \mathrm{C}(1.5 \mathrm{~h})$. After digestion, the solution was cooled and $50 \mathrm{~mL}$ of doubled distilled water was added. The solution was filtered and the contents of total $\mathrm{Cd}$, $\mathrm{Cu}, \mathrm{Cr}, \mathrm{Pb}, \mathrm{Ni}$, and $\mathrm{Zn}$ were quantified using ICP-AES (Yves Yobin JY 


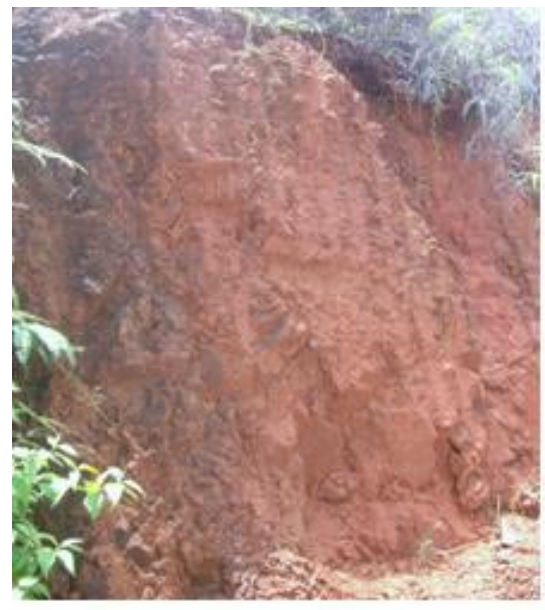

Bagacay soil

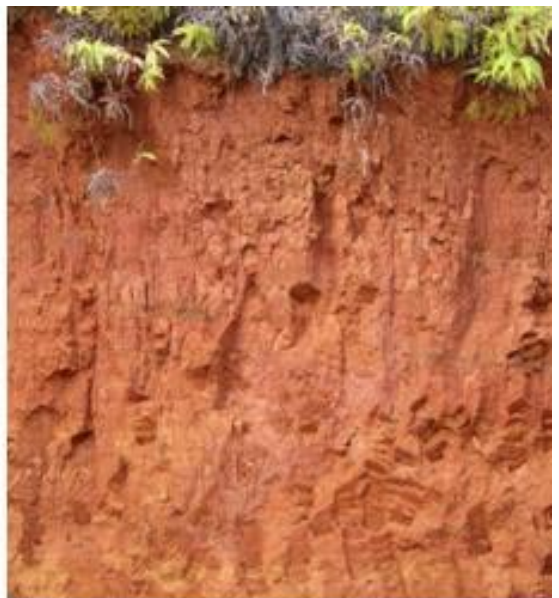

Salcedo soil

Figure 3. Soil profile of the two red soils evaluated in Samar, Philippines

70 plus). The available $\mathrm{Cd}, \mathrm{Cu}, \mathrm{Cr}, \mathrm{Ni}, \mathrm{Pb}$, and $\mathrm{Zn}$ were determined by $\mathrm{NH}_{4} \mathrm{NO}_{3}$ method (Schlichting et al. 1995) and the contents were quantified using ICP-AES. All analyses were done in duplicate samples and values are reported as mean.

\section{Statistical Analysis}

Pearson correlation analysis was done on selected measurable soil properties (clay, $\mathrm{pH}, \mathrm{OM}, \mathrm{CEC}, \mathrm{Fe}_{\mathrm{d}}, \mathrm{Al}_{\mathrm{d}}, \mathrm{Fe}_{\mathrm{o}}$, and $\mathrm{Al}_{\mathrm{o}}$ ) and total heavy metals (Table 2: $\mathrm{Cd}, \mathrm{Cu}, \mathrm{Cr}, \mathrm{Ni}, \mathrm{Pb}$, and $\mathrm{Zn}$ ) to assess the soil properties that control the behavior of heavy metals in the soils. The Pearson correlation analysis was done using the JMP software package (Version 8 , SAS Institute, USA). 


\section{RESULTS AND DISCUSSION}

\section{Total and Available Heavy Metals Content}

Table 2 shows the contents of total $\mathrm{Cd}, \mathrm{Cu}, \mathrm{Cr}, \mathrm{Ni}, \mathrm{Pb}$, and $\mathrm{Zn}$ of Bagacay and Salcedo soils. As can be seen, total Cd contents were below $0.09 \mathrm{mg} \mathrm{kg}^{-1}$ in both soils. The total $\mathrm{Cu}$ contents ranged from 56 to $96 \mathrm{mg} \mathrm{kg}^{-1}$ and 32 to $44 \mathrm{mg} \mathrm{kg}^{-1}$ in Bagacay and Salcedo soils, respectively. The total $\mathrm{Pb}$ contents ranged from 3 to $12 \mathrm{mg} \mathrm{kg}^{-1}$ with slightly higher values in Salcedo soil than in Bagacay soil, while the total $\mathrm{Zn}$ contents ranged from 58 to $69 \mathrm{mg} \mathrm{kg}^{-1}$ and the values did not vary considerably between the two soils. In Salcedo, the prolonged weathering of the serpentinite, which is known to contain high amounts of $\mathrm{Cr}$ and Ni (Huang, 1962; McGrath, 1995; Ellis et al., 2002), has

Table 2. Total heavy metal contents of the two red soils in Samar, Philippines

\begin{tabular}{lllllllc}
\hline Horizon & $\begin{array}{c}\text { Depth } \\
\mathrm{cm}\end{array}$ & $\begin{array}{c}\mathrm{Cd} \\
\mathrm{mg} \mathrm{kg}^{-1}\end{array}$ & $\mathrm{Cu}$ & $\mathrm{Cr}$ & $\mathrm{Ni}$ & $\mathrm{Pb}$ & $\mathrm{Zn}$ \\
\hline Bagacay soil & & & & & & & \\
\hline Ah & $0-5$ & 0.08 & 56 & 30 & 12 & 6.7 & 63 \\
BA & $5-20$ & 0.08 & 57 & 29 & 12 & 6.4 & 65 \\
Bt1 & $20-60$ & 0.03 & 61 & 33 & 14 & 6.3 & 64 \\
Bt2 & $60-100$ & 0.03 & 66 & 34 & 15 & 7.5 & 72 \\
Bt3 & $100-165$ & 0.09 & 60 & 10 & 12 & 6.8 & 68 \\
Bt4 & $165-225$ & 0.06 & 63 & 11 & 10 & 5.3 & 69 \\
Bt5 & $225-275$ & 0.06 & 69 & 8 & 7 & 4.9 & 69 \\
Bt6 & $275-350$ & 0.07 & 84 & 7 & 13 & 3.9 & 58 \\
Bt7 & $350-500$ & 0.06 & 96 & 8 & 11 & 3.2 & 58 \\
\hline Salcedo soil & & & & & & & \\
\hline Ah & $0-21$ & 0.00 & 32 & 1635 & 428 & 12 & 60 \\
Bo1 & $21-54$ & 0.04 & 40 & 1592 & 473 & 12 & 65 \\
Bo2 & $54-92$ & 0.05 & 44 & 1450 & 521 & 12 & 69 \\
Bo3 & $92-130$ & 0.01 & 41 & 1381 & 526 & 12 & 65 \\
Bo4 & $130-191$ & 0.03 & 39 & 1383 & 534 & 11 & 62 \\
Bo5 & $191-291$ & 0.00 & 37 & 1293 & 707 & 10 & 63 \\
Bo6 & $291-391$ & 0.00 & 40 & 1044 & 957 & 9 & 68 \\
Bo7 & $391-500$ & 0.00 & 37 & 1045 & 738 & 8 & 67 \\
\hline Critical value* & & $3-8$ & $60-125$ & $75-100$ & 100 & $100-400$ & $70-400$ \\
\hline
\end{tabular}

*According to Kabata-Pendias and Pendias (2001). 
resulted in elevated soil contents of total Cr (average: $1340 \mathrm{mg} \mathrm{kg}^{-1}$ ) and total $\mathrm{Ni}$ (average: $693 \mathrm{mg} \mathrm{kg}^{-1}$ ). The contents of total $\mathrm{Cr}$ and total $\mathrm{Ni}$ were 18 and 7 times larger than the critical soil total concentration of 75-100 and $100 \mathrm{mg} \mathrm{kg}^{-1}$ for $\mathrm{Cr}$ and $\mathrm{Ni}$, respectively (Kabata-Pendias and Pendias, 2001). Although a small fraction of the total $\mathrm{Cr}$ and total $\mathrm{Ni}$ in the soil are labile, mobile or biologically available (Kabata-Pendias and Pendias, 2001; McGrath, 1995), this fraction can enter the food chain through plant uptake and has the potential to pollute ground waters. Susaya et al. (2009) found that most farmers in the Salcedo site are growing food crops many of which contain elevated levels of $\mathrm{Cr}$ and $\mathrm{Ni}$ due to the high soil contents of these metals. These results suggest that the soil could pose health hazard to the farmers through dust inhalation or soil ingestion (Oliver, 1997) and consumption of food crops such a vegetables and root crops that are commonly grown in the area. Although no detailed health studies have yet been done in the area, many farmers reported unexplained health problems, which may be related to heavy metal toxicity. Another problem is that crops grown in soils high in $\mathrm{Ni}$ are more susceptible to mosaic virus infection than those in low Ni soils (Davis et al., 2001), suggesting that Salcedo soil is probably problematic when used for crop production. Under oxidizing condition, $\mathrm{Cr}$ is highly soluble and mobile in the soil as the $\mathrm{Cr}$ (VI) anion chromate $\left(\mathrm{CrO}_{4}{ }^{2-}\right)$ and bichromate $\left(\mathrm{HCrO}_{4}^{-}\right)$that are suspected to be carcinogenic (Ellis et al., 2002). On the other hand, the total $\mathrm{Cr}$ and total $\mathrm{Ni}$ contents were generally low in Bagacay soil since the slate parent material contained low amounts of these heavy metals. It likewise indicates that the half century of copper and pyrite mining activity a few kilometers away has not affected the soil studied probably because of the distance and it is not within the path of the dust coming from the mining site. However, it would be interesting to evaluate the level of contamination in the red soil very close or around the now abandoned mining site.

Table 3 reveals that the available $\mathrm{Cr}$ in Salcedo soil was higher (0.14-0.33 $\mathrm{mg} \mathrm{kg}^{-1}$; except Bo1 horizon) than the critical risk value of $0.05 \mathrm{mg} \mathrm{kg}^{-1}$, above which toxicity is considered to be possible. The acidic condition of Salcedo soil, which enhances Cr solubility, explains the elevated contents of available $\mathrm{Cr}$ in the soil (McGrath, 1995). The available $\mathrm{Cd}, \mathrm{Cu}, \mathrm{Pb}$, and $\mathrm{Zn}$ were low in the two soils, which is consistent 
Table 3. Available heavy metal contents of the two red soils in Samar, Philippines

\begin{tabular}{|c|c|c|c|c|c|c|c|}
\hline \multirow[b]{2}{*}{ Horizon } & \multirow{2}{*}{$\begin{array}{c}\text { Depth } \\
\mathrm{cm}\end{array}$} & $\mathrm{Cd}$ & $\mathrm{Cu}$ & $\mathrm{Cr}$ & $\mathrm{Ni}$ & $\mathrm{Pb}$ & $\mathrm{Zn}$ \\
\hline & & \multicolumn{6}{|c|}{$\mathrm{mg} \mathrm{kg}^{-1}$} \\
\hline \multicolumn{8}{|c|}{ Bagacay soil } \\
\hline $\mathrm{Ah}$ & $0-5$ & 0.01 & 0.03 & bdl & 0.02 & 0.01 & 0.25 \\
\hline Bt1 & $20-60$ & 0.01 & 0.04 & bdl & 0.02 & 0.01 & 0.26 \\
\hline Bt2 & $60-100$ & 0.01 & 0.12 & bdl & 0.05 & 0.06 & 0.28 \\
\hline Bt3 & $100-165$ & 0.01 & 0.13 & bdl & 0.04 & 0.22 & 0.20 \\
\hline \multicolumn{8}{|c|}{ Salcedo soil } \\
\hline Bo1 & $21-54$ & bdl & 0.01 & 0.01 & 0.10 & bdl & 0.02 \\
\hline Bo2 & $54-92$ & bdl & 0.02 & 0.14 & 0.46 & 0.02 & 0.04 \\
\hline Bo3 & $92-130$ & bdl & 0.03 & 0.33 & 0.57 & bdl & 0.09 \\
\hline Bo4 & $130-191$ & bdl & 0.03 & 0.26 & 0.71 & bdl & 0.09 \\
\hline Thresho & & 0.02 & 1.00 & 0.05 & 1.50 & 0.30 & 2.00 \\
\hline
\end{tabular}

with the low total contents of these heavy metals in the soils (Table 2). Despite the remarkably high total Ni contents, the available Ni was low and is likely due to the strong binding between $\mathrm{Ni}$ and soil clay minerals and $\mathrm{Fe}$ and $\mathrm{Al}$ oxides (Navarrete et al., 2007). This probably explains why no plants investigated in the Salcedo site met the criterion for a Ni hyperaccumulator plant (Susaya et al., 2009). However, prolonged consumption of different food crops with high Ni levels can induce accumulation of $\mathrm{Ni}$ above the recommended daily intake that could cause health problems (Susaya et al., 2009).

The total $\mathrm{Cr}$ and total $\mathrm{Ni}$ were positively correlated with clay $(p<0.001)$, dithionite extractable $\mathrm{Fe}\left(\mathrm{Fe}_{\mathrm{d}}: p<0.001\right)$ and $\mathrm{Al}$ oxides $\left(\mathrm{Al}_{\mathrm{d}}\right.$ : $p<0.001)$, but were negatively correlated with $\mathrm{OM}(p<0.05), \mathrm{CEC}$ $(p<0.001)$, and oxalate extractable $\mathrm{Fe}\left(\mathrm{Fe}_{\mathrm{o}}: p<0.001\right)$ and $\mathrm{Al}\left(\mathrm{Al}_{\mathrm{o}}\right.$ : $p<0.001$ ) (Table 4). This result implies strong affinity of clay, $\mathrm{Fe}$ and $\mathrm{Al}$ oxides to bind with $\mathrm{Cr}$ and $\mathrm{Ni}$ in the soils studied. This results conforms to the findings of Navarrete et al. (2007) who reported that $82-97 \%$ of $\mathrm{Cr}$ and $38-67 \%$ of $\mathrm{Ni}$ in Salcedo soil are strongly bounded to Fe oxides and other clay minerals (for example see Fig. 2). Similarly, Susaya et al. (2009) reported a strong correlation between total $\mathrm{Ni}$ and clay in the Salcedo soil. In the present study, the negative correlation between $\mathrm{Ni}$ and OM $(p<0.05)$ conforms to the findings of Kabata-Pendias and Sadurki 
(2004) who showed that the association of metals to OM was generally insignificant for $\mathrm{Ni}$. The total $\mathrm{Cu}(p<0.05)$ and total $\mathrm{Cd}(p<0.05)$ were positively correlated with CEC.

Table 4. Pearson correlation analysis between total heavy metals and selected soil properties of the two red soils in Samar, Philippines

\begin{tabular}{lcccccccc}
\hline & $\mathrm{pH}$ & Clay & $\mathrm{OM}$ & $\mathrm{CEC}_{7}$ & $\mathrm{Fe}_{\mathrm{d}}$ & $\mathrm{Al}_{\mathrm{d}}$ & $\mathrm{Fe}_{\mathrm{o}}$ & $\mathrm{Al}_{\mathrm{o}}$ \\
\hline Total $\mathrm{Cd}$ & -0.13 & $-0.53^{\mathrm{c}}$ & 0.47 & $0.55^{\mathrm{b}}$ & -0.46 & -0.42 & 0.23 & 0.41 \\
Total $\mathrm{Cu}$ & $-0.66^{\mathrm{b}}$ & $-0.93^{\mathrm{a}}$ & 0.43 & $0.69^{\mathrm{b}}$ & $-0.93^{\mathrm{a}}$ & $0.85^{\mathrm{a}}$ & 0.47 & $0.92^{\mathrm{a}}$ \\
Total $\mathrm{Cr}$ & $0.55^{\mathrm{b}}$ & $0.94^{\mathrm{a}}$ & $-0.56^{\mathrm{c}}$ & $-0.82^{\mathrm{a}}$ & $0.99^{\mathrm{a}}$ & $0.95^{\mathrm{a}}$ & $-0.59^{\mathrm{c}}$ & $-0.88^{\mathrm{a}}$ \\
Total $\mathrm{Ni}$ & $0.52^{\mathrm{b}}$ & $0.97^{\mathrm{a}}$ & $-0.57^{\mathrm{c}}$ & $-0.81^{\mathrm{a}}$ & $0.98^{\mathrm{a}}$ & $0.91^{\mathrm{a}}$ & $-0.60^{\mathrm{c}}$ & $-0.87^{\mathrm{a}}$ \\
Total $\mathrm{Pb}$ & 0.47 & $0.93^{\mathrm{a}}$ & $-0.61^{\mathrm{b}}$ & $-0.86^{\mathrm{a}}$ & $0.99^{\mathrm{a}}$ & $0.96^{\mathrm{a}}$ & $-0.68^{\mathrm{b}}$ & $-0.83^{\mathrm{a}}$ \\
Total $\mathrm{Zn}$ & $-0.56^{\mathrm{c}}$ & -0.38 & -0.13 & -0.03 & -0.22 & -0.10 & -0.31 & $0.52^{\mathrm{c}}$ \\
\hline${ }^{\mathrm{a}}$ Correlation is significant at the 0.001 level. & & & & & \\
${ }^{\mathrm{b} C o r r e l a t i o n}$ is significant at the 0.01 level. \\
'Correlation is significant at the 0.05 level.
\end{tabular}

\section{CONCLUSION}

Based on the results of the study, it maybe concluded that: a) the contents of total $\mathrm{Cr}$ and total $\mathrm{Ni}$ in the red Salcedo soil derived from sepentinite were high and exceeded the maximum allowable concentrations in agricultural soils; b) the total heavy metal contents of the red Bagacay soil from slate were low due to their low concentrations in the parent material; c) the contents of available form of the heavy metals studied were low in both red soils (except for available $\mathrm{Cr}$ in Salcedo soil); and d) there was no noticeable effect of the nearby mining site on the heavy contents of the slate-derived red Salcedo soil.

\section{REFERENCES}

ALLOWAY, B. J. 1995. Soil processes and the behaviour of metals. In: Heavy Metals in Soils (2nd ed.) (B. J. Alloway, ed). Blackie Academic and Professional, London, pp. 11-37.

ALLOWAY, B. J. 1997. Soil pollution and land contamination. In: 
Pollution: Causes, Effects and Control (3rd ed.) (R. M. Harrison, ed). Spriner, Berlin, pp: 318-338.

ASIO, V. B. and R. JAHN. 2007. Weathering of basalt and clay mineral formation in Leyte, Philippines. Philippine Agricultural Scientist 90:204-212.

CHEN,Z.S. and D. R.LEE. 1995. Heavy metals contents of representative agricultural soils in Taiwan. Journal of the Chinese Institute of Environmental Engineering 5:205-211.

CHEN, Z. S., G. J. LEE, and J. C. LIU. 2000. The effects of chemical remediation treatments on the extractability and speciation of cadmium and lead in contaminated soils. Chemosphere 41:235342

DAVIS, M. A., J. F. MURPHY, R. S. BOYD. 2001. Nickel increases susceptibility of a nickel hyperaccumulator to Turnip mosaic virus. J Environ Qual 30:85-90.

ELLIS, A. S., T. M. JOHNSON, and T. D. BULLEN. 2002. Chromium isotope and the fate of hexavalent chromium in the environment. Science 295:2060-2062.

HUANG, W. T. 1962. Petrology. McGraw-Hill Book Co., New York.

KABATA-PENDIAS, A., and H. PENDIAS. 2001. Trace Elements in Soils and Plants (3rd ed). CRC Press, Boca Raton.

KABATA-PENDIAS, A., and W. SADURSKI. 2004. Trace elements and compounds in soil. In: Elements and Their Compounds in the Environment (E. Merian, M. Anke, M. Ihnat, and M. Stoeppler, eds). Occurrence, Analysis and Biological Relevance (2nd ed). New York: Wiley-VCH.

McGRATH, S. P. 1995. Chromium and nickel. In: Heavy Metals in 
Soils (2nd ed.) (B. J. Alloway, ed). Blackie Academic and Professional, London, p. 152-178.

NAVARRETE, I. A., V. B. ASIO, R. JAHN, and K. TSUTSUKI. 2007. Characteristics and genesis of two strongly weathered soils in Samar, Philippines. Aust J Soil Res 45:153-163.

OLIVER, M. A. 1997. Soil and human health: a review. Eur J Soil Sci 48:573-592.

PUSCHENREITER, M., O. HORAK, W. FRIESEL, and W. HARTL. 2005. Low-cost agricultural measures to reduce heavy metal transfer into the food chain- a review. Plant Soil Environ 51: $1-11$.

PEREZ-SIRVENT, C., M. J. MARTINEZ-SANCHEZ, M. L. GARCIALORENZO, J. MOLINA, and M. L. TUDELA. 2009. Geochemical background levels of zinc, cadmium and mercury in anthropically influenced soils located in a semi-arid zone (SE, Spain). Geoderma 148: 307-317.

SCHLICHTING, E., H. P. BLUME, and K. STAHR. 1995. Bodenkundliches Practicum (2nd ed). Blackwell, Berlin.

REEVES, R. D. 2003. Tropical hyperaccumulators of metals and their potential for Phytoextraction. Plant and Soil 249:57-65.

SUSAYA, J. P., K. H. KIM, V. B. ASIO, Z. S. CHEN, I. A. NAVARRETE. 2009. Quantifying nickel in soils and plants in the ultramafic area in Philippines. Environmental Monitoring and Assessment 167:504-514.

U.S. ENVIRONMENTAL PROTECTION AGENCY. 1986. Acid digestion of sediments, sludge, and soils. In: Test Methods for Evaluating Soil Waste (USEPA, ed). SW-846, USEPA, Cincinnati, OH, U.S.A. 